In Ke Chung Kim and Robert D. Weaver, eds., Biodiversity and Landscapes (New York: Cambridge University Press, 1994), pages 47-60.

3

\title{
Creation: God and endangered species
}

HOLMES ROLSTON, III

\section{Religious value and the God Committee}

When the United States Congress lamented the loss of species, they declared that species have "esthetic, ecological, educational, historical, recreational, and scientific value to the Nation and its people" (Endangered Species Act of 1973, sec. 2a). Religious value is missing from this list. Perhaps Congress would have overstepped its authority to declare that species carry religious value. But for many Americans this is the most important value. Christians or Jews will add that these species are also of religious value, and not only to Americans but to God. Defending the freedom of religion, guaranteed in the Constitution, Congress might well have insisted that the species of plants and animals on our landscape ought to be conserved because such life is of religious value to the Nation and its people.

Though God's name does not appear in the Endangered Species Act itself, it does occur in connection with the Act. The protection Congress authorized for species is quite strong in principle. Interpreting the Act, the U.S. Supreme Court insisted "that Congress intended endangered species to be afforded the highest of priorities" (TVA vs. Hill, 174). Since "economic" values are not among the listed criteria either but must sometimes be considered, Congress, in 1978 amendments, authorized a high-level, interagency committee to evaluate difficult cases. This committee may permit human development at the cost of extinction of species. In the legislation, this committee is given the rather nondescript name "The Endangered Species Committee," but almost at once it was nicknamed "the God Committee." The name mixes jest with theological insight and reveals that religious value is implicitly lurking in the Act. Any who decide to destroy species take, fearfully, the prerogative of God.

In the practical conservation of biodiversity in landscapes, concerned with habitat, breeding populations, DDT in food chains, or water flows to maintain fish species, it might first seem that God is the ultimate irrelevancy. In fact, when 
one is conserving life, ultimacy is always nearby. The practical urgency of onthe-ground conservation is based in a deeper respect for life. Extinction is forever; and, when danger is ultimate, absolutes become relevant. The motivation to save endangered species can and ought to be pragmatic, economic, political, and scientific; deeper down it is moral, philosophical, and religious.

\section{Adam, Noah, and the prolific Earth}

Genesis! Take that word seriously. In the Hebrew stories, the "days" (events) of creation are a series of divine imperatives that empower Earth with vitality. "The earth was without form and void, and darkness was upon the face of the deep; and the Spirit of God was moving over the face of the waters. And God said, 'Let there be ... ' " (Genesis 1.2-3). "Let the earth put forth vegetation." "Let the earth bring forth living things according to their kinds" (Genesis 1.11, 24). "Let the waters bring forth swarms of living creatures" (Genesis 1.20). "Swarms" is, if you wish, the Biblical word for biodiversity.

A prolific Earth generates teeming life, urged by God. The Spirit of God is brooding, animating the Earth, and Earth gives birth. As we would now say, Earth speciates. When Jesus looks out over the fields of Galilee, he recalls how "the earth produces of itself" (Mark 4.28) spontaneously (in Greek: "automatically"). God reviews this display of life, finds it "very good," and bids it continue. "Be fruitful and multiply and fill the waters in the seas, and let birds multiply on the earth" (Genesis 1.22). In current scientific vocabulary, there is a dispersal, conservation by survival over generations, and niche saturation up to carrying capacity. The fauna is included within the covenant. "Behold I establish my covenant with you and your descendants after you, and with every living creature that is with you, the birds, the cattle, and every beast of the earth with you" (Genesis 9.5). In modern terms, the covenant was both ecumenical and ecological. Earth is a promised planet, chosen for abundant life. Adam's first job was to name this swarm of creatures, a project in taxonomy.

The Bible also records the first Endangered Species Project - Noah and his ark! That story is quaint and archaic, as much parable as history, teaching how God wills for each species on Earth to continue, despite the disruptions introduced by humans. Although individual animals perish catastrophically, God has an "adequate concern and conservation" for species - the species come through. After the Flood, God reestablishes "the covenant which I make between me and you and every living creature that is with you, for all future generations" (Genesis 9.12-13). Humans are to repopulate the earth, but not at threat to the other species; rather, the bloodlines must be protected at threat of divine reckoning (Genesis 9.1-7). The Biblical authors had no concept of 
genetic species but used instead the vocabulary of bloodlines. The prohibition against eating the blood is a sign of respect for these bloodlines.

The Endangered Species Act and the God Committee are contemporary events, but it can be jarring to set beside them these archaic stories. The stories are not only archaic in being couched in outmoded thought forms; they are archaic in that they are about aboriginal truths. The Noah story is antiquated genre, but the Noah threat is imminent today and still at the foundations. The story is a kind of myth teaching a perennial reverence for life. The ancient myth has, for the first time ever, become tragic fact. Humans have more understanding than ever of the speciating processes, more predictive power to foresee the intended and unintended results of their actions, and more power to reverse the undesirable consequences. If there is a word of God here, emerging out of the primordial past, it is "Keep them alive with you" (Genesis 6.19).

Indeed, these primitive stories sometimes exceed the recent legislation in the depths of their insights. Noah is not told to save just those species that are of "esthetic, ecological, educational, historical, recreational and scientific value" to people. He is commanded to save them all. These swarms of species are often useful to humans, and on the Ark clean species were given more protection than others. Noah was not simply conserving global stock and here, man is not the measure of things. The Noah story teaches sensitivity to forms of life and the biological and theological forces producing them. What is required is not human prudence but principled responsibility to the biospheric Earth, to God.

Today, preservation of species is routinely defended in terms of medical, agricultural, and industrial benefits. Other species may be indirectly useful for the resilience and stability they provide in ecosystems. High-quality human life requires a high diversity of species. However, such humanistic justifications for the preservation of species, although correct and required as part of endangered species policy, fall short of Noah's environmental ethics. These are good reasons but not the best, because they do not value these species for what they are in themselves, under God. These reasons are inadequate for either Hebrew or Christian faith, neither of which is simply humanistic about species. Facing the next century, turning the millennium, there is growing conviction among theologians that theology has been too anthropocentric. The nonhuman world is a vital part of Earth's story.

Biology and theology are not always easy disciplines to join, and we shall have more to say about that. One conviction they do share is that the ecosystemic Earth is prolific. Seen from the side of biology, this is called speciation, biodiversity, selective pressures for adapted fit, maximizing offspring in the next generation, niche diversification, species packing, and carrying capacity. Seen from the side of theology this trend toward diversity is a good thing, a 
godly thing. This fertility is sacred. Endangered species raise the "God" question because they are one place we come near the ultimacy in biological life. Earth is valuable, able for value, a system that generates valuable life. This genesis is, in biological perspective, "of itself," spontaneous, autonomous; and biologists find nature to be prolific, even before the God question is raised. Afterward, theologians wish to add that in such a prolific world, explanations may not be over until one detects God in, with, and under it all.

\section{Resources and sources}

The Genesis stories quickly mix human resources with divine sources. "Behold, I have given you every plant yielding seed which is upon the face of all the earth, and every tree with seed in its fruit; you shall have them for food" (Genesis 1.29). Placed in a garden, the couple are commanded "to till it and keep it" (Genesis 2.10). "The Lord God made for Adam and his wife garments of skins, and clothed them" (Genesis 3.21). After the Flood, animals are given as food. So there is no contesting that the biodiversity on the Genesis landscape includes an ecology that supports an economy. The story is about sources as much as resources. In terms of the two kinds of values missing from the Endangered Species Act, the economic values are recognized but entwined with religious values. If some of these species are good for food (or medicine or industry), Genesis warrants saving them on such account, but Genesis teaches this inseparably from a more central teaching that the values carried by species are vitally sacred.

Christians have often and admirably focused on economic values, insisting on political provision for jobs, food, shelter, and health care. In endangered species policy, the values that Christians wish to defend are often the more foundational and vital. Perhaps God wills a good life in a promised land; but without its fauna and flora, the land cannot fulfill all its promise.

One cannot look to the market to produce or protect the multiple values that the Nation and its people enjoy from the myriad species inhabiting the landscape, since many of these values carried by species are not, or not simply, economic ones. A pristine natural system, with its full complement of species, is a religious resource, as well as a scientific, recreational, aesthetic, or economic one. So we can call these species resources if we like, but there is more. If they are nothing but our human resources, it seems to profane them, to forget the pleasure that their Creator takes in this creation.

That explains why, confronting wildness, humans know the sense of the sublime. We get transported by forces awe-full and overpowering, by the signature of time and eternity. Being among the archetypes, a landscape, a forest, or a sea swarming with its kinds is about as near to ultimacy as we can 
come in the natural world - a vast scene of birth and death, sprouting, budding, flowering, fruiting, passing away, passing life on. We feel life's transient beauty sustained over chaos. Nature, swarming with its kinds, is a wonderland. "Praise the Lord from the earth you sea monsters and all deeps, fire and hail, snow and frost, stormy wind fulfilling his command! Mountains and all hills, fruit trees and all cedars! Beasts and all cattle, creeping things and flying birds!" (Psalm 148.8-9) "Thou crownest the year with thy bounty; the tracks of thy chariot drip with fatness. The pastures of the wilderness drip, the hills gird themselves with joy, the meadows clothe themselves with flocks, the valleys deck themselves with grain, they shout and sing for joy" (Psalm 65.11-13).

In contrast with the surrounding religions from which Biblical faith emerged, the natural world is disenchanted; it is neither God, nor is it full of gods; but it remains sacred, a sacrament of God. Though nature is an incomplete revelation of God's presence, it remains a mysterious sign of divine power. The birds of the air neither sow nor reap yet are fed by the heavenly Father, who notices the sparrows that fall. Not even Solomon is arrayed with the glory of the lilies, though the grass of the field, today alive, perishes tomorrow (Matthew 6). There is in every seed and root a promise. Sowers sow, the seed grows secretly, and sowers return to reap their harvests. God sends rain on the just and unjust. "A generation goes, and a generation comes, but the earth remains forever" (Ecclesiastes 1.4).

\section{Randomness and creativity}

But it is not always easy to join biology and theology. To put the problem in a contrasting pair of keywords: Is Earth by "design" or "accident"? Before Darwin, the world seemed well designed, species were adapted for their niches, fixed in kind, going back to an original special creation. Just as watches indicated a watchmaker, rabbits indicated a Rabbitmaker. After Darwin, there are random, blind mutations, the survival of the accidentally better adapted, and the evolution of species. There was no original creation at all, rather a billion years of accident and groping. Rather than God's first creating and subsequently preserving all of Earth's teeming species, species have come and gone in a constant and sometimes catastrophic turnover. All species, Homo sapiens included, are here by luck. Earth is not a watch, but a jungle; not a well-designed Eden, but a contingent chaos. Jacques Monod, a Nobel prizewinner, has claimed that natural history is "an enormous lottery presided over by natural selection, blindly picking the rare winners from among numbers drawn at utter random" (Monod, 1972, p. 138). Recently, David Raup has put catastrophism back into paleontology (Raup, 1988), and Stephen Gould has learned from the Burgess shale that the species on Earth, however wonderful, are chance riches 
and accidental life (Gould, 1989). If so, there can be no connection between God and species of whatever kind, much less endangered species.

Since we are touching creation and ultimacy, to keep the full picture in focus, we should notice that in physics, cosmologists have been finding this universe spectacularly fine-tuned for life. Hundreds of microphysical and astronomical phenomena, both contingencies and necessities, have to be almost exactly what they are if life is to be possible. Examples include the charges on electrons and protons, the strengths of the four binding forces, the scales, distributions, and ages of the stars, the expansion rate of the universe, the proportions of hydrogen and helium, and the structures of many heavier elements. Even before there is life, we already get a pro-life universe (Leslie, 1989).

If the contingencies and necessities of physics make life possible, so also do its indeterminacies. Just these microphysical indeterminacies provide the openness upon which a biological organism can superimpose its program. The organism is fine-tuned at the molecular level to nurse its way through the quantum states by electron transport, proton pumping, selective ion permeability, and so on. The organism interacts with the microphenomena (somewhat analogously to the way physicists participate in their observations), catching the random fluctuations to its advantage, setting up from above the conditions of probability. Through its biochemistry it shapes the course of the microevents that constitute its passage through the.world. Physics frees the world for the adventure of biology.

The difference between physics and biology is that biology is a historical science, where cumulative discoveries are coded into the organism over time. The laws of physies and chemistry are the same on Jupiter, on Mars, or in the galaxy Andromeda. But genetic coding, the cytochrome-c molecule, the citric acid cycle, photosynthesis, trilobites, dinosaurs, and grizzly bears are peculiar to Earth. They incorporate elements of randomness, but even more they represent creative achievements on Earth, now coded into the DNA and expressed in these species. Perhaps we are beginning to see that "accident" is not the full story; there is valuable creativity at work on our planet.

George Wald, also a Nobel prizewinner, differs with Monod: "This universe breeds life inevitably" (Wald, 1974, p. 9). Manfred Eigen, still another Nobel laureate, concludes, "that the evolution of life ... must be considered an inevitable process, despite its indeterminate course" (Eigen, 1971, p. 519). Melvin Calvin, still another Nobel laureate, concludes that life evolves "not by accident but because of the peculiar chemistries of the various bases and amino acids.... There is a kind of selectivity intrinsic in the structures." Far from being random, life is "a logical consequence" of natural principles (Calvin, 1975, p. 176). 
Despite the prolife world in physics, there is not much in the atoms themselves that enables us to predict that they will organize themselves in this remarkable way. Given chemistry as a premise, there is no deductive or inductive logic by which biology follows as a conclusion. Still there is this remarkable story to tell; and, when it happens, though it is no inference, neither does it seem nothing but accident. There seems to be some creativity intrinsic in the Earth by which these elements order themselves up to life. The story goes from zero to five million species in five billion years, passing through perhaps one billion species en route. By some mixture of inevitability and openness, given the conditions and constants of physics and chemistry, together with the biased Earth environment, life will somehow both surely and surprisingly appear. Once upon a time there was a primitive planetary environment in which the formation of living things had a high probability. In other words, the archaic Earth was a pregnant Earth. We may need not so much interference by a supernatural agency as the recognition of a marvelous endowment of matterenergy with a propensity toward life. Yet this endowment can be congenially seen, at a deeper level, as the divine creativity.

Where once there was but matter and energy, there appeared information, symbolically encoded, and life. There emerged a new state of matter, neither liquid, nor gaseous, nor solid, but vital. Randomness does not rule out creativity; randomness plus something to catch the upstrokes, something to code them and pass them on to the future, yields creativity, at the same time that it puts adventure, freedom, drama, and surprise into the storied evolutionary course.

The word "design" nowhere occurs in Genesis. There is divine fiat, divine doing, but the mode is an empowering permission that places productive autonomy in the creation. "Let Earth bring forth. ..." Biologists cannot deny this creativity; indeed, better than anyone else, biologists know that Earth has brought forth the natural kinds exuberantly over the millennia. The better question is not so much whether these creatures have design in the Craftsman/Architect-artifact/machine sense as whether they have value. Do they have inherent goodness? A thing does not have to be directly intended to have value. It can be the systemic outcome of a problem-solving process. If it results from such creativity, it is a valuable achievement.

\section{Struggle and perceptual perishing}

Perhaps the contrasting words that separate biology and religion are not "design" and "accident" but "good" versus "evil." Darwin once exclaimed that the evolutionary process was "clumsy, wasteful, blundering, low, and horribly 
cruel" (quoted in de Beer, 1962, p. 43). That is utter antithesis to the Genesis verdict of "very good." The governing principle is survival in a "nature red in tooth and claw" (Tennyson, In Memoriam A. H. H., Part LVI, Stanza 4). The wilderness contains only the thousandth part of creatures that sought to be, but rather became seeds eaten, young fallen to prey or disease. The wilderness swarms with kinds, as Genesis recognizes, but is a vast graveyard with a hundred species laid waste for one or two that survive. Blind and ever urgent exploitation is nature's driving theme, the survival of the fittest. George Williams, a foremost student of natural selection, concludes, "The cosmos stands condemned. The conscience of man must revolt against the gross immorality of nature" (Williams, 1988). Biologists are not altogether comfortable with the word "struggle," often preferring the notion of "adapted fit." Still, plenty of "struggle" remains in biology, and can it be godly?

The truth is that biological creativity is logically entwined with struggle and perishing. Life is the first miracle that comes out of nature, and death comes inevitably in its train. For an organism things can go wrong just because they can go right; a rock or a river never fails, but then again neither can ever succeed. In biology, we are not just dealing with causes and effects but with vitality and survival. A rock exists on its own, having no need of its environment, but an organism has welfare and interests; it must seek resources. Generation means regeneration. Life decomposes and recomposes. Religion, monotheism included, seldom teaches that creativity is without struggle. Life is green pastures found in the valley of the shadows, a table prepared in the midst of enemies (Psalm 23). By the third chapter Genesis is teaching that we eat our bread in sweat and tears.

In physics and chemistry there is no history refolding itself into compounding chapters; that comes with the evolutionary epic. There is also no suffering; that too comes in biology. With all life there is duress; and, with the evolution of sentience, there is suffering. Conservation in physics and chemistry is a foregone conclusion, for example, conservation of energy, mass, baryon number, or spin. Conservation in biology is vital and contingent. Life can be lost; indeed in higher forms individual life invariably is lost, although by reproducing and speciating life is conserved over the millennia.

The death of earlier creatures makes room for later ones, room to live, and, in time, to evolve. If nothing much had ever died, nothing much could have ever lived. The evolutionary adventure uses and sacrifices particular individuals, who are employed in, but readily abandoned to, the larger currents of life. Evolution both overleaps death and seems impossible without it. The element of struggle is muted and transmuted in the systemic whole. Something is always dying, something is always living on. 
In this perspective, biology and religion draw closer together. Israel is the rose of Sharon, blooming in the desert, the shoot budding forth out of the stump of Jesse. The root meaning of "Israel" is to struggle. Life is gathered up in the midst of its throes, a blessed tragedy, lived in grace through a besetting storm. Israel's founding historical memory is the Passover observance, a festival of the renewal of spring and of exodus releasing life from the powers that suppress it. Christianity intensifies this renewal in adversity with its central symbol: the cross. There is dying and rising to newness of life. Life is cruciform.

The grass, the flower of the field, is clothed with beauty today and gone tomorrow, cast into the fire. The sparrow is busy about her nest, and sings, and falls, noticed by God. There is trouble enough with each new day, and, beneath that, some providential power by which life persists over the vortex of chaos. We find life handed on, through ills and all, by wisdom genetically programmed, as well as in the cultural heritage of our forebears. The secret of life is only penultimately in the DNA, the secret of life ultimately is this struggling on to something higher. We dimly comprehend that we stand the beneficiaries of a vast providence of struggle that has resulted in the panorama of life. Just that sense of ongoing life, transcending individuality, makes life at the species level a religious value. Speciation lies at the core of life's brilliance, and to confront an endangered species, struggling to survive, is to face a moment of eternal truth.

\section{Nature, law, and grace}

Paradoxically, past the suffering, life is a kind of gift. Every animal, every plant has to seek resources, but life persists because it is provided for in the system. The swarms of creatures are not so much an ungodly jungle as a divinely inspired Earth. "Design" is not the right word; it is a word borrowed from mechanics and their machines. Genesis is the better word, with "genes" in it, the gift of autonomy and self-creation. Designed machines to not have any interesting history; clocks have no story lines. But organisms must live biographies, and such a story continues for several billion years. Such an Earthen providing ground is, in theological perspective, providential. Providential adventures do not so much have design as pathways. In grace accompanying a passage through history, there must be a genetic pathway available along which there can be a lineage of descent, ascent, exploration, and adventure. Monotheists who take genesis seriously do not suppose a Deux ex machina that lifts organisms out of their environment, redesigns them, and reinserts them with an upgraded design. Rather they find a divine creativity that leads and lures along available routes of Earth history. 
Laws are important in natural systems, but natural law is not the complete explanatory category for nature, any more than are randomness and chance. In nature, beyond the law is grace. There is creativity by which more comes out of less. Science prefers lawlike explanations without surprises. One predicts, and the prediction comes true. But, nevertheless, biology is full of unpredictable surprises. Our account of natural history will not be by way of implication, whether deductive or inductive. There is no covering law (such as natural selection), plus initial conditions (such as trilobites), from which one can deduce primates, any more than one can assume microbes as a premise and deduce trilobites in conclusion. Nor is there any induction (expecting the future to be like the past) by which one can expect trilobites later from procaryotes earlier, or dinosaurs still later by extrapolating along a regression line (a progression line!) drawn from procaryotes to trilobites. There are no humans invisibly present (as an acom secretly contains an oak) in the primitive eucaryotes, to unfold in a lawlike way. All we can do is tell the epic story eucaryotes, trilobites, dinosaurs, primates, persons who are scientists, ethicists, conservation biologists - and the drama may prove enough to justify it.

In only seeming contrast to Adam and Noah, who are trustees of the creation, Job rejoices in how the nonhuman creation is wild, free from the hand of man. "Who has let the wild ass go free? Who has loosed the bonds of the swift ass, to whom I have given the steppe for his home, and the salt land for his dwelling place? ... He ranges the mountain as his pasture, and he searches after every green thing" (Job 39.5-8). [Even in Biblical times, the wild ass was an endangered species; nevertheless it persisted in Palestine until 1928, when it became extinct.] "Is it by your wisdom that the hawk soars, and spreads his wings toward the south? Is it at your command that the eagle mounts up and makes his nest on high? On the rock he dwells and makes his home in the fastness of the rocky crag. Thence he spies out the prey; his eyes behold it afar. His young ones suck up blood; and where the slain are, there is he" (Job 39.26-40.2). "The high mountains are for the wild goats; the rocks are a refuge for the badgers. ... The young lions roar for their prey, seeking their food from God.... O.Lord, how manifold are thy works! In wisdom hast thou made them all" (Psalm 104.18-24).

Though outside the hand of man, the wild animals are not outside either divine or biological order. The Creator's love for the creation is sublime precisely because it does not conform to human purposes. That God is personal as revealed in human cultural relations does not mean that the natural relationship of God to hawks and badgers is personal, nor should humans treat such creatures as persons. They are to be treated with appropriate respect for their wildness. The meaning of the word "good" and "divine" is not the same in 
nature and in culture. Just as Job was pointed out of his human troubles toward the wild Palestinian landscape, it is a useful, saving corrective to a simplistic Jesus-loves-me;-this-I-know, God-is-on-my-side theology to discover vast ranges of creation that have nothing to do with satisfying our personal desires.

What the wildlands with their swarms of species do "for us," if we must phrase it that way, is teach that God is not "for us" humans alone. God is "for" these wild creatures too. In Earth's wildness there is a complex mixture of authority and autonomy, a divine imperative that there be communities (ecosystems) of spontaneous and autonomous ("wild") creatures, each creature defending its form of life. A principal insight that Biblical faith can contribute to conservation is to take the concept of wildlife "sanctuaries" in national policy to its logical and religious conclusion. A wildlife sanctuary is a place where nonhuman life is sacrosanct, that is, valued in ways that transcend human uses. In that sense Christian conviction wants sanctuaries not only for humans, but also for what wild lives are in themselves and under God. Since there is hardly a stretch of landscape in our nation not impoverished of its native fauna and flora, we want sanctuaries especially for endangered species.

Religious persons can bring a perspective of depth to biological conservation. Species are a characteristic expression of the creative process. The swarms of species are both presence and symbol of forces in natural systems that transcend human powers and human utility. Generated from earth, air, fire, and water, these fauna and flora are an archetype of the foundations of the world. We want a genetic account in the deeper sense. The history of Earth, we are claiming, is a story of the achievement, conservation, and sharing of values. Earth is a fertile planet, and in that sense, fertility is the deepest category of all, one classically reached by the category of creation. This creative systemic process is profoundly but partially described by evolutionary theory, a historical saga during which spectacular values are achieved and at the core of which the critical category is value, commonly termed "survival value," better interpreted as valuable information, coded genetically, that is adapted for, apt for "living on and on" (survival), for coping, for life's persisting in the midst of its perpetual perishing. Such fecundity is not finally understood until seen as divine creativity.

This history has been a struggling through to achieve something higher, to better adapted fit and more complex and diverse forms, and there is no particular cause to assume that the grim accounts of it are the adult, biologically correct ones, and the gracious, creative, charismatic ones childish, naive, or romantic. Or, shifting the meaning of "romantic" to its original sense, life is a romance, an epic of vital conflict and resolution producing rich historical novelty. 


\section{Religious conservation biologists}

Whatever you may make of God, biological creativity is indisputable. There is creation, whether or not there is a Creator, just as there is law, whether or not there is a Lawgiver. Some biologists decline to speak of creation, because they fear a Creator lurking beneath. Well, at least there is genesis, whether or not there is a Genitor. Ultimately, there is a kind of creativity in nature demanding either that we spell nature with a capital $\mathbf{N}$, or pass beyond nature to nature's God. Biologists today are not inclined, nor should they be as biologists, to look for explanations in supernature, but biologists meanwhile find a nature that is super! Superb! Science teaches us to eliminate from nature any suggestions of teleology, but it is not so easy for science to talk us out of genesis. What has managed to happen on Earth is startling by any criteria. Biologists may doubt whether there is a Creator, but no biologist can doubt genesis.

Ernst Mayr, one of the most eminent living biologists, concludes, "Virtually all biologists are religious, in the deeper sense of the word, even though it may be a religion without revelation.... The unknown and maybe unknowable instills in us a sense of humility and awe" (Mayr, 1982, p. 81). "And if one is a truly thinking biologist, one has a feeling of responsibility for nature, as reflected by much of the conservation movement" (Mayr, 1985, p. 60). "I would say," concludes Loren Eiseley, at the end of The Immense Journey, "that if 'dead' matter has reared up this curious landscape of fiddling crickets, song sparrows, and wondering men, it must be plain even to the most devoted materialist that the matter of which he speaks contains amazing, if not dreadful powers, and may not impossibly be ... 'but one mask of many worn by the Great Face behind'" (Eiseley, 1957, p. 210).

Annie Dillard, a poet, once found herself terrified at the evolutionary ordeal, although she too can, in other moments be amply religious about it. Overlooking the long, odious scene of suffering and violence, she cries out: "I came from the world, I crawled out of a sea of amino acids, and now I must whirl around and shake my fist at that sea and cry shame" (Dillard, 1974, p. 177). Must she? There is nothing shameful about amino acids rising out of the sea, speciating, swarming over Earth, assembling into myriads of species, not the least of which is Homo sapiens, with mind to think and hand to act. If I were Aphrodite, rising from the sea, I think I would turn back, reflect on that event, and rather raise both hands and cheer. And if I came to realize that my rising out of the misty seas involved a long struggle of life renewed in the midst of its perpetual perishing, I might well fall to my knees in praise.

J. B. S. Haldane was asked by some theologians what he had concluded from biology about the character of God. He replied that God had an inordinate fondness for beetles, since he made so many of them. Haldane went on to say 
that the marks of biological nature were its "beauty," "tragedy," and "inexhaustible queerness" (Haldane, 1932, pp. 167-169). My experience is that this beauty approaches the sublime; the tragedy is perpetually redeemed with the renewal of life, and that the inexhaustible queerness recomposes as the numinous. "Nature is one vast miracle transcending the reality of night and nothingness" (Eiseley 1960, p. 171).

Biology produces many doubts; here are two more. I doubt whether you can be a conservation biologist without a respect for life, and the line between respect for life and reverence for life is one that I doubt that you can always recognize. If anything at all on Earth is sacred, it must be this enthralling creativity that characterizes our home planet. If anywhere, here is the brooding Spirit of God. Whatever biologists may make of the mystery of life's origins, they almost unanimously conclude that the catastrophic loss of species that is at hand and by our hand is tragic, irreversible, and unforgivable. Difficult to join though biology and theology sometimes are, they are difficult to separate in their respect for life. Earlier we worried that the processes of creation might be ungodly. But faced with extinction of these processes, biology and theology quickly couple to reach one sure conclusion. For humans to shut down Earth's prolific creativity is ungodly.

\section{References}

Calvin, Melvin (1975). Chemical evolution. American Scientist, 63, 169-177.

de Beer, Gavin (1962). Reflections of a Darwinian. London: Thomas Nelson and Sons.

Dillard, Annie (1974). Pilgrim at Tinker Creek. New York: Harper \& Row.

Eigen, Manfred (1971). Selforganization of matter and the evolution of biological macromolecules. Die Naturwissenschaften, 58, 465-523.

Eiseley, Loren (1975). The Immense Journey. New York: Vintage.

Eiseley, Loren (1960). The Firmament of Time. New York: Atheneum.

Gould, Stephen Jay (1989). Wonderful Life: The Burgess Shale and the Nature of History. New York: W. W. Norton.

Haldane, J. B. S. (1932, 1966). The Causes of Evolution. Ithaca: Cornell University Press.

Leslie, John (1989). Universes. New York: Routledge.

Monod, Jacques (1972). Chance and Necessity. New York: Random House.

Mayr, Ernst (1982). The Growth of Biological Thought. Cambridge, MA: Harvard University Press.

Mayr, Ernst (1985). How biology differs from the physical sciences. In Evolution at a Crossroads, ed. David J. Depew and Bruce H. Weber. Cambridge, MA: MIT Press.

Raup, David M. (1988). Changing views of natural catastrophe. In The Great Ideas Today. Chicago: Encyclopedia Britannica.

United States Congress, Endangered Species Act of 1973. 87 Stat. 884.

United States Supreme Court, Tennessee Valley Authority vs. Hill (1978). 437 US 153. 
Wald, George (1974). Fitness in the universe: choices and necessities. In Cosmochemical Evolution and the Origins of Life, ed. J. Oro et al. Dordrecht, Netherlands: D. Reidel.

Williams, George (1988). Huxley's evolution and ethics in sociobiological perspective. Zygom, 23, 383-407. 